\title{
Gosto musical e pertencimento social \\ O caso do samba e do choro no Rio de Janeiro e em São Paulo
}

\author{
Dmitri Cerboncini Fernandes e Carolina Pulici
}

Introdução

Referindo-se a um concerto de Dmitri Shostakovich interpretado pelo violoncelista Antonio Meneses e pela pianista Celina Szrvinski na capela do palácio Boa Vista, em Campos de Jordão, o crítico musical Arthur Nestrovski lamenta, não sem antes avaliar que era "como se menos que isso nem fosse música", que apenas "cento e poucas pessoas tinham o privilégio de escutar Meneses assim de perto [...] naquele cenário, com as montanhas cobrindo a vista de lado a lado da transparente capela do arquiteto Paulo Mendes da Rocha”, e faz um apelo a que os sociólogos brasileiros investiguem esse privilégio que, ao mesmo tempo, corresponde inevitavelmente "à verdade daquela música de câmara, que afinal é para ser ouvida em 'câmara'” (Nestrovski, 2006, p. E2).

Se é certo que as práticas culturais que integram a assim chamada cultura erudita evocam, no Brasil, os grupos socialmente privilegiados, toda tentativa de desvincular o valor distintivo de tais expressões artísticas de sua distribuição social está condenada de antemão. Tida, no passado, por instrumento excessivamente nobilitante das elites (Fernandes, 1960), a "grande música" assume, até os dias de hoje, um papel não negligenciável nas estratégias de distinção vigentes nas relações de classe, no mínimo porque quanto mais se avança em direção a esse gênero bastante reconhecido na tradicional hierarquia dos valores culturais maiores as diferenças estatísticas associadas à escolaridade e à classe social ${ }^{1}$.

1. Assim, por exemplo, o gosto pela música clássica é, na cidade de São Paulo, fortemente associado 
Mas se a fruição da música clássica é índice seguro de pertencimento a um meio socialmente favorecido - o que revela que no Brasil, assim como na França e na Inglaterra, as práticas culturais mais tradicionais são também as mais discriminantes (Donnat, 1999; Warde e Bennett, 2008) -, as preferências referentes a gêneros musicais supostamente "subalternos" e mais recentes na história da arte, como os denominados "populares", não deixam de se pautar pelas hierarquias estruturantes da sociedade, confirmando a opinião do músico brasileiro Carlos Lyra, para quem “a bossa nova não é música de geração. É de classe social” (Arantes, 2005, p. E1).

Este artigo baseia-se em uma pesquisa empírica cujos resultados apontam que a já conhecida tese da homologia entre o espaço da produção cultural e o espaço de seu consumo (Bourdieu, 1979) permanece atual e ainda pode instigar novos achados em realidades nacionais e culturais distintas: com efeito, e no que tange ao choro e ao samba na cidade de São Paulo e na capital carioca, pudemos verificar que ela se mantém operante até mesmo internamente a esses dois gêneros musicais populares e seus sub-ramos. Assim, e como não seria possível pensar as bases sociais do gosto musical ignorando-se os desdobramentos específicos do universo da produção que circunscreve o próprio espaço dos possíveis musicais, apresentaremos, inicialmente, alguns elementos concernentes aos gêneros em tela no campo musical brasileiro para, em seguida, demonstrar que, malgrado a atual popularidade acadêmica do postulado do ecletismo cultural e dos consumidores “omnívoros" (Bryson, 1997; Peterson e Simkus, 1992; Bellavance, Ratté e Valex, 2004), há fortes indícios de que o espaço de produção e difusão do samba e do choro em São Paulo e no Rio de Janeiro continua a manter uma relação de homologia com o espaço social em que são recrutados os ouvintes/amantes desse tipo de música.

Fontes e metodologia da pesquisa

Analisaremos de início resultados provenientes de 160 questionários aplicados entre os anos de 2006 e 2009 a um público de oito casas de espetáculo localizadas em São Paulo e no Rio de Janeiro. A divisão efetuada entre os locais em que se desenvolveu a pesquisa de campo obedeceu à ordem estritamente proporcional, ou seja, vinte questionários foram aplicados em cada uma das oito casas selecionadas, dez deles tendo sido respondidos por homens e os outros dez por mulheres. A escolha de tal cifra universal foi parcialmente aleatória: longe de atender a qualquer 
parâmetro de fiabilidade estatística, de níveis de significância ou de buscar qualquer espécie de representatividade do domínio estudado, a sondagem aqui apresentada vale única e exclusivamente como instrumento revelador de tendências presentes em meio ao público correspondente em cada ponto de coleta de dados.

Por mais incipiente que seja em termos estatísticos o caráter do experimento proposto, tal investida justifica-se pela escassez de pesquisas empíricas deste viés no Brasil ${ }^{2}$. Ademais, embora não atinja o coeficiente de uma amostra significativa referente ao público presente nos espetáculos selecionados - o que só a realização de um survey específico poderia vir a realizar -, adotamos determinados controles no intento de minorar o viés da amostra de tamanho reduzido. Assim, antes da escolha das pessoas que responderiam aos questionários, realizamos uma coleta prévia de informações com base em observação etnográfica. Desse modo, por exemplo, após verificarmos que as diferentes faixas etárias estavam desigualmente representadas, efetuávamos uma distribuição de questionários tão condizente quanto possível com as proporções observadas: se percebêssemos a presença de aproximadamente $80 \%$ de presentes com faixa etária aparente entre 30 e 40 anos, mas um pequeno número de idosos e jovens, nós entrevistávamos oito homens incluídos na primeira faixa etária, mais um idoso e um jovem. Ainda que algo impressionista, esse critério de pré-seleção foi importante para contornar um obstáculo central a empreitadas deste feitio: o relativo baixo número de entrevistados que, inelutavelmente, distorce a amostra. Por fim, para reforçarmos a contribuição ao debate em torno da tese da homologia entre o espaço das posições sociais e o espaço dos estilos de vida (Featherstone, 1995; Coulangeon, 2004; Fridman e Ollivier, 2004; Duval, 2011), na parte final do artigo cotejaremos nossa "micro" análise numérica com uma grandiosa pesquisa posta em marcha pelo Ibope sobre a audiência de rádio no Brasil no intervalo de 1994 a 1999. Esta análise comparativa apontou que as tendências observadas em ambos os levantamentos são muito próximas, corroborando destarte as conclusões resultantes do experimento "artesanal".

2. Além disso, as poucas investigações estatísticas voltadas ao consumo cultural no Brasil adotam classificações grosseiras que, a respeito dos gostos musicais, abrigam sob a rubrica "música popular brasileira" gêneros tão díspares como o sertanejo, o samba, o pagode, o rock nacional e, ainda, o que se convencionou chamar de MPB (Botelho e Fiori, 2005, p. 62). Insistir que hoje as fronteiras da legitimidade cultural tornaram-se mais difusas (Fabiani, 2003) é uma coisa; pretender que um amador das canções de Chico Buarque valha o mesmo que um fã da banda Calypso não faria senão afirmar que toda e qualquer prática cultural garante as mesmas insígnias de estima social. Confundindo o que deveriam distinguir, tais taxonomias são, assim, desfavoráveis a estudos que, como o nosso, buscam avaliar a construção de fronteiras sociais a partir das preferências culturais. 
"Choro", "samba tradicional", "samba de raiz" e "pagode comercial"

Escolhemos para figurar como objetos de nossa investida dois dos mais tradicionais gêneros musicais populares urbanos brasileiros: o samba e o choro, cujas histórias imbricadas se reproduziram a partir da constituição de um microcosmo artístico possuidor de parâmetros relativamente autônomos (Napolitano, 2007). Há de se ressaltar a ênfase concedida ao conceito de "relativamente", pois, por maior que seja seu grau de autonomia e "legalidade própria" (presença de instituições especializadas em seu funcionamento, de legisladores e críticos próprios etc.), ele não deixa de consistir em um subsistema social capaz de transfigurar através de sua linguagem específica as disputas simbólicas e lutas de classificação entre distintas classes e frações de classe em nome da representação legítima do mundo social.

Diversos autores (Fernandes, 2010; Wasserman, 2002; Stroud, 2008; McCann, 2004; Trotta, 2006; Sandroni, 2001) constataram que o modo pelo qual atuaram os agentes engajados na legitimação dessas expressões musicais - personagens encarados como portadores de modos de ver e de fazer crer oriundos de suas posiçóes sociais - levou à cisão das manifestações filiadas a tais gêneros ao longo do século $\mathrm{xx}$. Mais do que isso, em todos os trabalhos citados observou-se claramente que o desenlace desse processo acabou sendo, em diversos momentos históricos, a criação de subgêneros dotados de princípios estéticos e de públicos hierarquicamente diferenciados convivendo de maneira tensa em uma mesma arena, consistindo, portanto, tais gêneros em instâncias ricas em conflitos simbólicos que podem revelar a transfiguração de cisões sociais em meio ao que aparenta pertencer apenas ao domínio estético.

Quando o que se tem em vista é o estado das artes a partir da década de 1990, a literatura sublinha como novidade a ascensão de um subgênero do samba de forte apelo comercial, prenhe de inovações em termos de instrumentação musical (uso de instrumentos musicais eletrificados, como contrabaixo, teclados, guitarras, bateria etc., em sua maioria estranhos à tradição do samba), de tema (amor romântico, declamado de forma exagerada por meio de versos eivados de equívocos gramaticais e conotações sensuais) e de arranjos (gravações e apresentações que contam com uma miríade de instrumentos musicais executando simultaneamente trinados, arpejos e demais exibicionismos de técnica ao lado de vocalizações que abusam de mal colocados vibratos, elementos configuradores do kitsch musical), cujos principais artistas, jovens suburbanos despidos de capitais e chancela no universo da música popular, lograram, por um lado, amealhar estrondoso êxito em vendas e aparição na grande mídia e, por outro, atrair a fúria dos estabelecidos e seus porta-vozes. Esse subgênero do samba terminou conhecido pejorativamente como "pagode comercial", e seus 
representantes proeminentes eram os grupos Soweto, Exaltasamba, Katinguelê, Raça Negra, Só Pra Contrariar, entre outros ${ }^{3}$.

Na outra ponta da legitimidade cultural situava-se o "samba tradicional", subgênero reduto dos prestigiosos artistas do samba. Personagens como Paulinho da Viola, Elton Medeiros, Nelson Sargento, as Velhas Guardas das escolas de samba do Rio de Janeiro etc. encarnavam os sentinelas dos valores desse universo (simplicidade e discrição, tanto no que tange ao comportamento na vida quanto no que diz respeito aos versos, às melodias e aos arranjos que compunham as canções; emprego de instrumentos musicais repertoriados na tradição e emblemáticos da autenticidade, como cavaquinho, violão, pandeiro, cuíca, surdo, tamborim etc.; adesão aos valores do desinteresse e ausência de grandes esquemas comerciais etc.) $)^{4}$.

Tais baluartes costumavam servir de referência a outro grupamento, o dos antigos pagodeiros, pagodeiros "de raiz", aqui denominados "sambistas de raiz". Tratava-se de fomentadores de um subgênero do samba com origem na década de 1980 que se encontram a meio caminho do reconhecimento dos ortodoxos estabelecidos e legitimados. Se no passado sofreram reproches em razão de inovações que promoveram (enxerto de instrumentação musical estranha à tradição, como banjo, repique de mão e tantã; participação no maculador esquema comercial do pagode dos anos 1990; madrinha suspeita no circuito da "autenticidade" - Beth Carvalho - etc.), na atualidade são respeitados por parte dos "sambistas tradicionais" e evocados enquanto fontes de inspiração e legitimidade pelos novos pagodeiros que se querem fazer seus rebentos musicais. Seus representantes são o Grupo Fundo de Quintal e derivados, como Zeca Pagodinho, Jorge Aragão, Almir Guineto, entre outros 5 .

No degrau mais nobre da hierarquia cultural relativa ao microcosmo em questão figura o gênero musical "choro". Reunindo musicistas que dividiam espaço com o "samba tradicional" em termos institucionais e artísticos, o "choro" diferenciava-se dos demais gêneros e subgêneros da música popular por se prestar majoritariamente à execução melódica, não possuindo em geral, portanto, letras versificadas, fator de atração àqueles que buscam na canção certa identificação imediata e/ou sensorial. As altas quantidade e qualidade de capitais culturais e sociais, o estudo e a busca

3. Para análises detalhadas concernentes ao "pagode comercial", ver Fernandes (2010) e Trotta (2006).

4. Há muita produção elegíaca e biográfica sobre o samba tradicional e seus baluartes, mas pouca bibliografia que tome tal subgênero na atualidade a fim de tecer uma análise distanciada em termos sócio-históricos e estéticos. Ver Stroud (2008), Sandroni (2001), Fernandes (2010), Rivron (2010), Napolitano e Wasserman (2000) e Barros (2010).

5. Sobre este subgênero, ver Trotta (2006), Pereira (2003) e Fernandes (2010). Sobre as frequentes e variadas tentativas de enobrecimento cultural via contato com as manifestações artísticas já bem posicionadas na ordem das legitimidades (compositor de rock que experimenta um arranjo musical clássico, grafiteiro que tenta expor seu trabalho nas galerias de arte etc.), consultar Lahire (2006). 
perpétua por aperfeiçoamento técnico consistiam nas características distintivas de seus autores, geralmente provenientes de famílias de músicos profissionais ou amadores. O domínio de toda a tradição da música popular, a aproximação da erudição e o virtuosismo no manejo dos instrumentos musicais sacralizados (como bandolim, cavaquinho, violão de sete cordas etc.) também eram requisitos necessários à filiação a esse gênero de alto rendimento simbólico e baixa rentabilidade econômica ${ }^{6}$.

Considerando-se os quatro gêneros e/ou subgêneros musicais brevemente caracterizados, investigaremos em seguida o modo pelo qual as estruturas melódicas, instrumentais, rítmicas e harmônicas das canções, os discursos dos agentes e suas disposições e as instituições que os acolhem podem vir a se vincular a distintos públicos consumidores de produções e aparições. Para testar a hipótese de que a autonomia desse domínio, embora existente, é relativa, já que não está a salvo de injunções que fazem adentrar lógicas heterônomas ao domínio da arte, investigar-se-á a existência de uma homologia - e não de uma identidade - entre o campo das classes sociais e o campo da produção musical relativamente autônomo, ou seja, nem totalmente dependente, nem totalmente independente.

As casas de espetáculos e as condições de coleta dos dados

A seleção das oito casas de espetáculos contou também com parâmetros preestabelecidos. Em primeiro lugar, respeitamos o critério "localização central", pois, em tese, esse fator dificultaria a presença maciça de público específico e regionalizado em termos de bairro ou zona nas cidades de São Paulo e Rio de Janeiro. Além do mais, o acesso se tornaria equanimemente fácil ou difícil, a depender da região em que os entrevistados residissem.

Na rua Rui Barbosa encontra-se o teatro Denoy de Oliveira, de propriedade da CPC-Umes - Centro Popular de Cultura da União Municipal dos Estudantes Secundaristas de São Paulo. Herdeiro da famosa sigla de resistência dos anos 1960, o espaço comporta um público de cerca de 120 pessoas. O ingresso para o espetáculo de uma hora e meia, realizado todas as segundas-feiras do primeiro semestre de 2009, era gratuito. Ali tinha lugar o especial O choro e sua história, musical comandado por Isaías do Bandolim. De forma pedagógica, Isaías e convidados contextualizavam a biografia dos compositores do choro homenageados na sessão de música e história que se instalava. No Rio de Janeiro houve a preferência, nesse quesito, pela aplicação do questionário ao público da casa Comuna do Semente, bar que data de meados de 
1997, situado em casarão histórico próximo aos Arcos da Lapa. Às segundas-feiras apresentava-se o violonista de formação erudita Zé Paulo Becker, concertista respeitado nos meios chorísticos pelo virtuosismo e técnica de execução. O preço era de dezesseis e dezoito reais, para mulheres e homens respectivamente.

Já o teatro Fecap, fundado em 2006 e situado na avenida Liberdade, em São Paulo, foi projetado especialmente para receber eventos musicais. Contando com quatrocentas cadeiras, espetáculos de figurões da MPB e do samba "autêntico" são frequentes por lá, casos de Paulinho da Viola, Zélia Duncan, Mônica Salmaso, entre outros. O público foi entrevistado em dia de apresentação da cantora Cristina Buarque acompanhada pelo conjunto Terreiro Grande, big band devotada a reviver clássicos do samba. O espetáculo abrangia a obra do sambista Candeia, com o ingresso a vinte reais. O homólogo no Rio de Janeiro do "samba tradicional" foi o célebre Carioca da Gema, bar da Lapa existente desde meados de 2000, que funciona em antigo casarão da rua Mem de Sá, com capacidade para trezentos pagantes. Entre mesas de madeira, apresentava-se em um pequeno palco Tereza Cristina e o grupo Semente ao preço de vinte reais a entrada.

Próxima à praça Franklin Roosevelt, no bairro da Consolação, situa-se o espaço Você Vai se Quiser, nome inspirado em composição de Noel Rosa. O local, capaz de acolher aproximadamente trezentas pessoas, existe desde meados de 2005 e possui um grupo próprio de musicistas que se apresenta aos sábados, praticando o preço de vinte reais como couvert artístico. O repertório predominante compunha-se de canções de Zeca Pagodinho, Fundo de Quintal, Beth Carvalho, configurando-se, por conseguinte, no território eleito em São Paulo para a averiguação do público aficionado do "samba de raiz". Na cidade do Rio de Janeiro, optou-se pelo Lapa 40", que abriga a mesma espécie de samba. Trata-se de construção recente na rua do Riachuelo, onde grandes salões se repartem em quatro ambientes e andares distintos. Um deles aloja apresentações de artistas variados, não consistindo, portanto, em casa específica de samba. No dia da aplicação do questionário o espetáculo era do cantor, musicista e compositor Arlindo Cruz, ex-Grupo Fundo de Quintal, com custo de 25 reais aos homens e vinte reais às mulheres.

O público do último subgênero, o "pagode comercial”, teve como representante em São Paulo os frequentadores da casa Porto Alcobaça. Posicionado na avenida Francisco Matarazzo, o local reunia capacidade para acolhimento de mais de 1.500 pessoas em sua grandiosa pista de shows, o que em si é um dado da maior importância $^{7}$. No dia selecionado para a aplicação dos questionários apresentava-se o grupo

7. “[...] pelo fato de que dá uma boa medida do grau de independência ('arte pura,' 'pesquisa pura' etc.) ou de subordinação ('arte comercial', 'pesquisa aplicada' etc.) com relação à demanda do 'grande público' 
Turma do Pagode, então expressivo vendedor de discos. O preço praticado na ocasião era de gratuidade às mulheres até a meia-noite e, após este horário, de vinte reais para as cadastradas no sítio virtual do estabelecimento e de trinta reais para as não cadastradas. Já entre os homens o preço era de vinte reais para os cadastrados e trinta para os não cadastrados. No Rio de Janeiro, por fim, a aplicação relativa ao público do "pagode comercial" foi realizada em espetáculo do grupo paulista Exaltasamba, na Fundição Progresso, outra casa na região da Lapa que recebe variados artistas do cenário musical brasileiro. Ao lado dos Arcos, a Fundição Progresso é capaz de acolher o mesmo número de sua homóloga Porto Alcobaça, em São Paulo, praticando, além do mais, preços semelhantes: ambos os sexos desembolsavam vinte reais para assistir aos "pagodeiros comerciais" em uma noite de sexta-feira.

O espaço da difusão e o espaço do consumo: uma relação de homologia

Tendo em vista testar a hipótese segundo a qual "à hierarquia socialmente reconhecida das artes - e, no interior de cada uma delas -, dos gêneros, escolas ou épocas, corresponde a hierarquia social dos consumidores" (Bourdieu, 2008, p. 9), a variável dependente a ser utilizada nos cruzamentos a seguir será a relativa às casas de espetáculo visitadas. As demais se postarão em função desta que se afigura como o mais importante elemento distintivo dentro da análise das práticas, das hierarquias e das competências culturais aqui proposta. Encarnação dos diferentes gêneros/ subgêneros em discussão, tais locais serão relacionados com as características etárias, socioeconômicas, educacionais e residenciais do público interrogado.

Verifica-se, primeiramente, que a maioria do público entrevistado apresenta idade entre 21 e 30 anos (58,2\% de toda a amostra), sendo que os mais jovens se concentram nas casas de espetáculo onde o "pagode comercial" dá o tom (na Porto Alcobaça havia 85\% com menos de 25 anos, enquanto na Fundição Progresso 70\% dos entrevistados declararam possuir menos que 25 anos). Tal resultado corrobora as pesquisas que mostraram que os jovens são os mais propensos às práticas de fraca legitimidade cultural (Lahire, 2004).

Nos espaços do choro a idade dos entrevistados aparenta melhor distribuição e maior número de pessoas mais velhas ( $55 \%$ com mais de 40 anos de idade no Denoy de Oliveira e $40 \%$ com mais de 30 anos na Comuna do Semente), vindo logo em seguida o teatro Fecap e o Carioca da Gema (25\% com mais de 40 anos de idade e

\footnotetext{
e às sujeições ao mercado, logo, da presumida adesão aos valores do desinteresse, o volume do público (portanto, sua qualidade social) constitui sem dúvida o indicador mais seguro e mais claro da posição ocupada no campo" (Bourdieu, 1996, p. 247, grifos nossos).
} 
44,4\% com mais de 35 anos, respectivamente). A distribuição do Você Vai se Quiser expressa grande concentração de indivíduos na faixa dos 26 a 35 anos (65\% dos entrevistados), algo semelhante ao que ocorre no Lapa $40^{\circ}$, cujos frequentadores de 21 a 30 anos de idade somam $70 \%$.

TABELA 1

Local de Coleta versus Faixa Etária

\begin{tabular}{l|c|c|c|c|c|c|c|c|c}
\hline \multirow{2}{*}{$\begin{array}{l}\text { LOCAL DE COLETA } \\
\text { DOS DADOS }\end{array}$} & \multicolumn{7}{|c|}{ FAIXA ETÁRIA } \\
\cline { 2 - 10 } & 16 a 20 & 21 a 25 & 26 a 30 & 31 a 35 & 36 a 40 & 41 a 50 & 51 a 60 & 61 a 70 & 71 ou mais \\
\hline $\begin{array}{l}\text { Teatro Denoy de Oliveira } \\
\text { (choro, sp) }\end{array}$ & $15,0 \%$ & $20,0 \%$ & $10,0 \%$ & - & - & $15,0 \%$ & $20,0 \%$ & $15,0 \%$ & $5,0 \%$ \\
\hline $\begin{array}{l}\text { Comuna do Semente } \\
\text { (choro, RJ) }\end{array}$ & $5,0 \%$ & $20,0 \%$ & $35,0 \%$ & $15,0 \%$ & $15,0 \%$ & - & $5,0 \%$ & $5,0 \%$ & - \\
\hline $\begin{array}{l}\text { Teatro Fecap } \\
\text { (samba tradicional, sP) }\end{array}$ & - & $10,0 \%$ & $45,0 \%$ & $15,0 \%$ & $5,0 \%$ & $10,0 \%$ & $5,0 \%$ & $10,0 \%$ & - \\
\hline $\begin{array}{l}\text { Carioca da Gema } \\
\text { (samba tradicional, RJ) }\end{array}$ & - & $27,8 \%$ & $16,7 \%$ & $11,1 \%$ & $22,2 \%$ & $11,1 \%$ & $11,1 \%$ & - & - \\
\hline $\begin{array}{l}\text { Você Vai se Quiser } \\
\text { (samba de raiz, sP) }\end{array}$ & - & $25,0 \%$ & $60,0 \%$ & $5,0 \%$ & - & $10,0 \%$ & - & - & - \\
\hline $\begin{array}{l}\text { Lapa 40 } \\
\text { (samba de raiz, RJ) }\end{array}$ & - & $50,0 \%$ & $20,0 \%$ & $10,0 \%$ & $10,0 \%$ & - & $10,0 \%$ & - & - \\
\hline $\begin{array}{l}\text { Porto Alcobaça } \\
\text { (pagode comercial, sP) }\end{array}$ & $30,0 \%$ & $55,0 \%$ & $10,0 \%$ & - & $5,0 \%$ & - & - & - & - \\
\hline $\begin{array}{l}\text { Fundição Progresso } \\
\text { (pagode comercial, RJ) }\end{array}$ & $30,0 \%$ & $40,0 \%$ & $20,0 \%$ & - & - & $10,0 \%$ & - & - & - \\
\hline \begin{tabular}{l} 
TOTAL \\
\hline
\end{tabular} & $10,1 \%$ & $31,0 \%$ & $27,2 \%$ & $7,0 \%$ & $7,0 \%$ & $7,0 \%$ & $6,3 \%$ & $3,8 \%$ & $0,6 \%$ \\
\hline
\end{tabular}

Malgrado o baixo número de entrevistados, o que torna os resultados desse primeiro cruzamento um tanto imprecisos, a combinação entre os demais dados disponíveis confirma certas tendências que estão a distinguir e a hierarquizar os públicos, como se o gosto musical fosse, em grande parte, uma espécie de retradução simbólica das diferenças objetivamente inscritas nas condições de existência. Desse modo - e como veremos a seguir -, os resultados das questões socioeconômicas e educacionais dão a ver que o menos legítimo "pagode comercial”, por exemplo, recruta maior número de jovens desprovidos de ambos os capitais.

No tocante às profissões, elas se encontram agrupadas em cinco grandes categorias. Procuramos estabelecer tal repartição com base nas profissões relatadas in loco. A fim de não reduzirmos todas as diferenças de posicionamento social a diferenças de classe (Weber, 2000; Elias e Scotson, 2000), efetuamos um recorte em termos 
econômicos e também de status, utilizando como base da taxonomia proposta as pesquisas de Pierre Bourdieu e sua equipe sobre o consumo cultural (Bourdieu e Darbel, 2003; Bourdieu, 1979). Como tais investigações foram levadas a cabo na França dos anos de 1960 e 1970, procedemos a adaptações concernentes à realidade do mercado de trabalho brasileiro contemporâneo, pois novas formas de emprego surgiram no período, e o status social de algumas teria se modificado. Vale ressaltar que tal proposição figura como solução prática e circunscrita às questões investigadas aqui, tendo o único mérito de proporcionar solução de compromisso que contornasse o engessamento que uma opção pelo uso de escalas pré-construídas de agrupamentos de profissões viesse a ocasionar.

A divisão estabelecida baseia-se no gradiente iniciado com trabalhos manuais pesados e socialmente estigmatizados, que quase não requerem conhecimentos escolares - faxineira, pedreiro, pintor -, e avança pelos de baixa qualificação - trabalhos de pouca rentabilidade simbólica e econômica que demandam algum conhecimento específico e que, em contrapartida, não exigem esforços braçais, como operador de telemarketing, motoboy, recepcionista, segurança, baixo comércio -, pelos de média qualificação ou técnicos ligeiramente superiores - gerentes de banco, técnicos em informática, analistas de sistema, baixo funcionalismo público, técnicos em enfermagem -, pelos superiores em termos econômicos - advogados, economistas, médicos, engenheiros - e pelos superiores em termos culturais - professores, artistas, jornalistas, arquitetos. Por meio dessa classificação das profissões declaradas, buscamos abarcar as diferenciações em termos de benefícios materiais, mas, também, honoríficos, pois de nada adiantaria o uso de escalas logicamente "perfeitas" que não lidassem com os dados restritos de que dispomos.

É possível observar, sem grande dificuldade, que nas casas Porto Alcobaça e Fundição Progresso, que difundem o "pagode comercial”, praticamente não há um único representante das profissões mais estimadas socialmente (55\% dos presentes na Fundição Progresso situam-se nos grupos mais modestos, o mesmo ocorrendo com 90\% do público da Porto Alcobaça) e que a maioria dos frequentadores do teatro Fecap, Carioca da Gema, do teatro Denoy de Oliveira e da Comuna do Semente, isto é, dos locais que propagam os dois gêneros/subgêneros de mais alta legitimidade cultural, a saber, o "samba tradicional" e o choro, possui profissões de corte superior $(70 \%, 80 \%$, $65 \%$ e $75 \%$, respectivamente, com leve preponderância de status para os locais do choro, não por acaso a expressão musical mais bem posicionada de todas na ordem dominante das legitimidades culturais). Os dois polos de profissões dominantes contam ainda exatos 55\% no Você Vai se Quiser e no Lapa $40^{\circ}$, o que retrata a composição social híbrida dos aficionados do "samba de raiz", divididos entre uma parcela detentora de maiores trunfos e outra representativa de profissóes desvalorizadas ( $45 \%$ e $30 \%$ em 
cada uma das casas). Se existe uma não negligenciável concentração de indivíduos de condição socialmente desfavorecida entre os locais que abrigam o "samba tradicional" nas duas cidades ( $40 \%$ no teatro Fecap e $25 \%$ no Carioca da Gema), nos espaços do "choro", contudo, tais categorias sociais se fazem bem menos presentes (apenas 10\% na Comuna do Semente e 20\% no teatro Denoy de Oliveira).

TABELA 2

Local de Coleta versus Profissão

\begin{tabular}{|c|c|c|c|c|c|c|}
\hline \multirow[b]{2}{*}{$\begin{array}{l}\text { LOCAL DE } \\
\text { C O LE TA } \\
\text { DOS DADOS }\end{array}$} & \multicolumn{6}{|c|}{ PROFISSÃO } \\
\hline & $\begin{array}{l}\text { Proletariado } \\
\text { clássico, dona } \\
\text { de casa, faxi- } \\
\text { neira etc. }\end{array}$ & $\begin{array}{l}\text { Proletariado mo- } \\
\text { derno, motoboy, } \\
\text { autônomo, técni- } \\
\text { cos em geral etc. }\end{array}$ & $\begin{array}{l}\text { Trabalhadores com } \\
\text { curso superior, ou co- } \\
\text { nhecimentos especí- } \\
\text { ficos, informática etc. }\end{array}$ & $\begin{array}{l}\text { Profissões eco- } \\
\text { nomicamente } \\
\text { superiores }\end{array}$ & $\begin{array}{l}\text { Profissões cul- } \\
\text { turalmente su- } \\
\text { periores }\end{array}$ & Não aplica \\
\hline 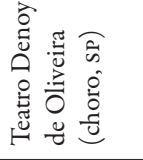 & - & $15,0 \%$ & $5,0 \%$ & $20,0 \%$ & $45,0 \%$ & $15,0 \%$ \\
\hline 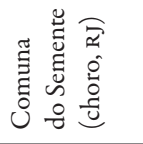 & $5,0 \%$ & $5,0 \%$ & - & $15,0 \%$ & $60,0 \%$ & $15,0 \%$ \\
\hline 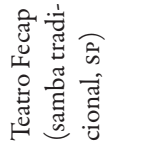 & $5,0 \%$ & $15,0 \%$ & $10,0 \%$ & $10,0 \%$ & $60,0 \%$ & - \\
\hline 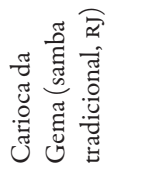 & - & $25,0 \%$ & - & $25,0 \%$ & $45,0 \%$ & $5,0 \%$ \\
\hline 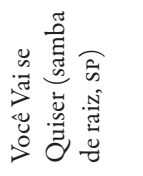 & - & $10,0 \%$ & $35,0 \%$ & $10,0 \%$ & $45,0 \%$ & - \\
\hline 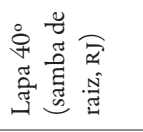 & $5,0 \%$ & $25,0 \%$ & - & $50,0 \%$ & $5,0 \%$ & $15,0 \%$ \\
\hline 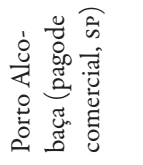 & $15,0 \%$ & $55,0 \%$ & $20,0 \%$ & - & - & $10,0 \%$ \\
\hline 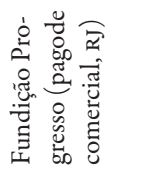 & $15,0 \%$ & $30,0 \%$ & $10,0 \%$ & - & $5,0 \%$ & $40,0 \%$ \\
\hline TOTAL & $5,6 \%$ & $22,5 \%$ & $10,0 \%$ & $16,3 \%$ & $33,1 \%$ & $12,5 \%$ \\
\hline
\end{tabular}


Quando se visualiza o patrimônio de disposições culturais dos entrevistados, a hierarquização dos públicos torna-se ainda mais nítida, visto que a maior parte dos presentes na Porto Alcobaça e na Fundição Progresso - que propagam as expressões musicais menos valorizadas do ponto de vista cultural - apresenta, ela também, as propriedades escolares mais desqualificadas nos mercados de trabalho e de títulos acadêmicos ${ }^{8}$. Nesse cenário, poder-se-ia indagar se os diferentes juízos estéticos não estariam na verdade a dissimular as não menos diversas divisões de ordem social (Duval, 2011).

Com efeito, a maioria dos que compareceram na Porto Alcobaça possui apenas o ensino médio completo (55\%), caso que contrasta com todos os outros, até mesmo com o da Fundição Progresso, que neste quesito não se destacava negativamente (20\% detinham somente o ensino médio). Nenhum dos entrevistados da Porto Alcobaça sequer cursava uma pós-graduação, enquanto na Fundição Progresso esse número também era mínimo, fator de equanimidade entre os amantes do "pagode comercial". Outro dado que atesta o quanto os amadores desse subgênero musical são predominantemente desmunidos em termos escolares reside no fato de que $45 \%$ dos entrevistados da Porto Alcobaça que terminaram um curso superior ou que estão matriculados num deles realizam-no em faculdades privadas de menor qualidade e prestígio, o mesmo ocorrendo com os $80 \%$ diplomados presentes na Fundição Progresso, uma vez que $45 \%$ deles se formaram em instituições menos prestigiosas 9

Entre os frequentadores dos outros estabelecimentos, nota-se, para além do maior número de universitários em termos absolutos, sobretudo no que se refere às casas de espetáculos que abrigam o "samba tradicional" e o "choro" (80\% no teatro Fecap, 90\% no Carioca da Gema, 75\% no Denoy de Oliveira e 75\% na Comuna), a presença marcante de estudantes ou egressos de instituições universitárias públicas ou privadas tradicionais, conforme a Tabela 4 (55\% dos entrevistados do teatro Fecap e 65\% do Carioca da Gema cursam ou cursaram seus estudos universitários em prestigiosas

8. Pode-se dizer que a gratuidade do espetáculo para as mulheres até a meia-noite na Porto Alcobaça não gerou distorções, pois os homens presentes que deviam pagar de vinte a trinta reais dispunham de atributos socioeconômicos semelhantes e igualmente deficitários. Se na Fundição Progresso o fator preço impingido a ambos os sexos e o local de apresentação do Exaltasamba, isto é, na prestigiosa região da Lapa, podem ter auxiliado a elevar o perfil social dos frequentadores, nada os iguala aos públicos do choro e do "samba tradicional" carioca. Outro dado que minaria eventual crítica economicista à possível distorção causada pelo preço dos ingressos em cada casa é o de que, no caso do choro em São Paulo, por exemplo, o espetáculo era gratuito e, ainda assim, a distinção entre o seu público e o do "pagode comercial" não poderia ser maior.

9. As universidades/faculdades privadas foram classificadas em dois grupos: o grupo I abriga as instituições mais tradicionais e reputadas, como a PUC, o Mackenzie, a ESPM e a Faap. Em contrapartida, o grupo II abarca as universidades/faculdades privadas mais recentes e que não investem em pesquisa. 
TABELA 3

Local de Coleta versus Escolaridade

\begin{tabular}{|c|c|c|c|c|}
\hline \multirow{2}{*}{$\begin{array}{l}\text { LOCAL DE COLETA } \\
\text { DOS DADOS }\end{array}$} & \multicolumn{4}{|c|}{ PROFISSÃO } \\
\hline & Fundamental & Médio & Superior & Pós-graduação \\
\hline $\begin{array}{l}\text { Teatro Denoy de Oliveira } \\
\text { (choro, sP) }\end{array}$ & $5,0 \%$ & $20,0 \%$ & $65,0 \%$ & $10,0 \%$ \\
\hline $\begin{array}{l}\text { Comuna do Semente } \\
\text { (choro, } \mathrm{RJ} \text { ) }\end{array}$ & $10,0 \%$ & $15,0 \%$ & $45,0 \%$ & $30,0 \%$ \\
\hline $\begin{array}{l}\text { Teatro Fecap } \\
\text { (samba tradicional, SP) }\end{array}$ & - & $20,0 \%$ & $60,0 \%$ & $20,0 \%$ \\
\hline $\begin{array}{l}\text { Carioca da Gema } \\
\text { (samba tradicional, RJ) }\end{array}$ & $5,0 \%$ & $5,0 \%$ & $70,0 \%$ & $20,0 \%$ \\
\hline $\begin{array}{l}\text { Você Vai se Quiser } \\
\text { (samba de raiz, sP) }\end{array}$ & $20,0 \%$ & $15,0 \%$ & $50,0 \%$ & $15,0 \%$ \\
\hline $\begin{array}{l}\text { Lapa } 40^{\circ} \\
\text { (samba de raiz, RJ) }\end{array}$ & - & $5,0 \%$ & $95,0 \%$ & - \\
\hline $\begin{array}{l}\text { Porto Alcobaça } \\
\text { (pagode comercial, sp) }\end{array}$ & - & $55,0 \%$ & $45,0 \%$ & - \\
\hline $\begin{array}{l}\text { Fundição Progresso } \\
\text { (pagode comercial, RJ) }\end{array}$ & - & $20,0 \%$ & $75,0 \%$ & $5,0 \%$ \\
\hline TOTAL & $5,0 \%$ & $19,4 \%$ & $63,1 \%$ & $12,5 \%$ \\
\hline
\end{tabular}

TABELA 4

Local de Coleta versus Instituiçôes Universitárias

\begin{tabular}{|c|c|c|c|c|}
\hline \multirow{2}{*}{$\begin{array}{l}\text { LOCAL DE COLETA } \\
\text { DOS DADOS }\end{array}$} & \multicolumn{4}{|c|}{ UNIVERSIDADE } \\
\hline & Universidade Pública & Universidade Privada I & Universidade Privada II & Não aplica \\
\hline $\begin{array}{l}\text { Teatro Denoy de Oliveira } \\
\text { (choro, SP) }\end{array}$ & $20,0 \%$ & $30,0 \%$ & $20,0 \%$ & $30,0 \%$ \\
\hline $\begin{array}{l}\text { Comuna do Semente } \\
\text { (choro, } \mathrm{RJ} \text { ) }\end{array}$ & $35,0 \%$ & $25,0 \%$ & $15,0 \%$ & $25,0 \%$ \\
\hline $\begin{array}{l}\text { Teatro Fecap } \\
\text { (samba tradicional, sp) }\end{array}$ & $40,0 \%$ & $15,0 \%$ & $25,0 \%$ & $20,0 \%$ \\
\hline $\begin{array}{l}\text { Carioca da Gema } \\
\text { (samba tradicional, } \mathrm{RJ} \text { ) }\end{array}$ & $40,0 \%$ & $25,0 \%$ & $30,0 \%$ & $5,0 \%$ \\
\hline $\begin{array}{l}\text { Você vai se quiser } \\
\text { (samba de raiz, SP) }\end{array}$ & $35,0 \%$ & $10,0 \%$ & $30,0 \%$ & $25,0 \%$ \\
\hline $\begin{array}{l}\text { Lapa } 40^{\circ} \\
\text { (samba de raiz, RJ) }\end{array}$ & $40,0 \%$ & $5,0 \%$ & $40,0 \%$ & $15,0 \%$ \\
\hline $\begin{array}{l}\text { Porto Alcobaça } \\
\text { (pagode comercial, sP) }\end{array}$ & - & - & $45,0 \%$ & $55,0 \%$ \\
\hline $\begin{array}{l}\text { Fundição Progresso } \\
\text { (pagode comercial, RJ) }\end{array}$ & $30,0 \%$ & $5,0 \%$ & $40,0 \%$ & $25,0 \%$ \\
\hline TOTAL & $30,0 \%$ & $14,4 \%$ & $30,6 \%$ & $25,0 \%$ \\
\hline
\end{tabular}


instituições, ao passo que as cifras para os frequentadores do Denoy de Oliveira e do Comuna são de 50\% e 60\%, respectivamente). Os espaços do "samba de raiz", subgênero mais legítimo do que o "pagode comercial”, mas menos legítimo que o choro e o "samba tradicional", a despeito de reunirem grande número de universitários (65\% no Você Vai se Quiser e 95\% no Lapa 40), atraem, em maioria, estudantes de estabelecimentos privados pertencentes ao grupo II (30\% no Você Vai se Quiser e $40 \%$ no Lapa $40^{\circ}$ ), o que os diferencia levemente dos locais mais consagrados e termina por reafirmar, por conseguinte, a composição social mista dessas casas, já observada na Tabela 2.

Atestando a inscrição da lógica social na lógica urbana (Marques, Scalon e Oliveira, 2008), a hierarquização dos públicos observada até aqui ressurge no que concerne ao bairro de residência dos entrevistados, já que as divisões sociais notadas também se refletem de maneira simétrica nesse quesito, conforme os dados apresentados na Tabela 5. Assim, entre os "sambistas de raiz", a metade exata dos frequentadores do Você Vai se Quiser reside em bairros centrais e a outra, em bairros periféricos, enquanto em seu homólogo Lapa $40^{\circ}$ quase metade (55\%) reside na região mais nobre do Rio de Janeiro, $20 \%$ em bairros periféricos e $25 \%$ não habitam aquela cidade ${ }^{10}$. Se a cidade é uma expressão do processo mais amplo de agregação de semelhantes e de segregação de estranhos, era de se esperar que entre os amantes do "samba tradicional" e do "choro", gêneros dotados de grande autoridade simbólica no campo musical, a maioria residisse nos bairros centrais (75\% para o caso do "samba tradicional" e $80 \%$ para o "choro" em São Paulo). No Rio de Janeiro, a cifra se mantém em relação ao "choro" (75\% nos bairros centrais), ao passo que o Carioca da Gema, que difunde espetáculos de "samba tradicional", contempla aqueles que vivem fora do Rio de Janeiro, consistindo em polo de turismo "cultural" dos que buscam o "verdadeiro" samba (70\% não residem no Rio de Janeiro, enquanto 20\% vivem nas regiões nobres e apenas $10 \%$ nos bairros periféricos).

Nessa linha de juízo, não admira que a maioria desprovida de propriedades passíveis de conferir estima social representada pelo público do "pagode comercial" habitasse as regiões mais carentes de São Paulo e do Rio de Janeiro, a despeito da localização central das casas de espetáculo selecionadas (75\% dos frequentadores da

10. Tomou-se como parâmetro para a construção do atributo "bairros centrais" aqueles que se localizam dentro do círculo do chamado "centro expandido" de São Paulo, de toda a Zona Sul carioca, a Zona Oeste próxima ao centro - Tijuca, Vila Isabel e adjacências -, e as regiões norte também coladas ao centro - São Cristóvão e adjacências. Os demais bairros são agrupados em "bairros periféricos”, que, no caso do Rio de Janeiro, compreendem também as cidades da Baixada Fluminense e em São Paulo, as cidades que formam a chamada região do $\mathrm{ABCD}$. As outras localidades declaradas que escaparam desse circuito foram computadas no quesito "não aplica". 
Porto Alcobaça e 45\% dos presentes na Fundição Progresso residem na região periférica, sendo este último, de longe, o maior número proporcional dos que residem em bairros afastados do circuito carioca). A propensão diferencial dos diferentes grupos sociais de fruírem dos subgêneros localizados nas regióes mais comerciais do campo musical revela-se ainda no fato de que somente a Fundição Progresso não atraía turistas na afamada região de samba no Rio de Janeiro, o que reforça o caráter de menor respeitabilidade e prestígio do "pagode comercial" - conhecido também como "pagode paulista" - em comparação com os outros gêneros e/ou subgêneros alçados ao estatuto de legítimos produtos de "exportação" carioca-popular.

TABELA 5

Local de Coleta versus Agrupados

\begin{tabular}{l|c|c|c}
\hline \multirow{2}{*}{ LOCAL DE COLETA DOS DADOS } & \multicolumn{2}{|c}{ BAIRROS AGRUPADOS SP-RJ } \\
\cline { 2 - 4 } & Bairros Centrais & Bairros Periféricos & Não aplica \\
\hline $\begin{array}{l}\text { Teatro Denoy de Oliveira } \\
\text { (choro, SP) }\end{array}$ & $80,0 \%$ & $15,0 \%$ & $5,0 \%$ \\
\hline $\begin{array}{l}\text { Comuna do Semente } \\
\text { (choro, RJ) }\end{array}$ & $75,0 \%$ & $10,0 \%$ & $15,0 \%$ \\
\hline $\begin{array}{l}\text { Teatro Fecap } \\
\text { (samba tradicional, sP) }\end{array}$ & $75,0 \%$ & $10,0 \%$ & $15,0 \%$ \\
\hline $\begin{array}{l}\text { Carioca da Gema } \\
\text { (samba tradicional, RJ) }\end{array}$ & $20,0 \%$ & $10,0 \%$ & $70,0 \%$ \\
\hline $\begin{array}{l}\text { Você Vai se Quiser } \\
(\text { samba de raiz, SP) }\end{array}$ & $50,0 \%$ & $50,0 \%$ & - \\
\hline $\begin{array}{l}\text { Lapa 40 } \\
\text { (samba de raiz, RJ) }\end{array}$ & $55,0 \%$ & $20,0 \%$ & $25,0 \%$ \\
\hline $\begin{array}{l}\text { Porto Alcobaça } \\
\text { (pagode comercial, sP) }\end{array}$ & $20,0 \%$ & $75,0 \%$ & $5,0 \%$ \\
\hline $\begin{array}{l}\text { Fundição Progresso } \\
\text { (pagode comercial, RJ) }\end{array}$ & $55,0 \%$ & $45,0 \%$ & - \\
\hline & & & \\
\hline
\end{tabular}

Como se vê, os subgêneros desqualificados pelas autoridades simbólicas mais reconhecidas no universo musical tendem a recrutar o público que ocupa as posições menos elevadas no espaço social. Assim, o "pagode comercial", de forma geral, atrai o público mais jovem e, também, o de menor quantidade e qualidade de capitais e que, em tese, seria mais exposto ao consumo de blockbusters musicais difundidos pelas rádios, programas de televisão e estratégias comerciais que compreendem o ciclo de rápido retorno do investimento realizado. Esse segmento localizado nas regiões menos elevadas da hierarquia social tenderia a se apropriar de mercadorias musicais consideradas "inautênticas" pelos detentores da autoridade musical legítima que 
sacramentam, antes, as expressões artísticas que, tal como o "samba tradicional" e o choro, logram safar-se do "descrédito que se liga ao sucesso comercial" (Bourdieu, 1996). Seriam ainda propensos ao consumo de estilos musicais de curta sobrevida e grande sucesso de vendas, quer dizer, os considerados tão heterodoxos e culturalmente indignos quanto o "pagode comercial", como é o caso do funk, do rap e do sertanejo. Não por acaso, e quando se leva em conta a hierarquia das maneiras de consumir, o "pagode comercial” divide o mesmo espaço físico (Porto Alcobaça e Fundição Progresso) relegado a esses ritmos depreciados pelos experts do gosto musical.

Se a escola engendra a pluralidade de experiências socializadoras e a heterogeneidade dos perfis culturais individuais (Lahire, 2006), não se pode apostar, neste caso, na eventual "correção" escolar dos aprendizados culturais "impróprios”, pois, como visto, os ouvintes das manifestações musicais menos legitimadas são, a um só tempo, os que não tiveram acesso às instituições que conferem os diplomas de maior prestígio e que expõem à frequentação de pessoas e ambientes que cultivam a cultura dotada de poder de sanção simbólica ${ }^{11}$.

Em contrapartida, e dando a ver mais uma vez a homologia entre a oferta musical e a hierarquia social do público, é na região mais elevada do espaço social que se recrutam prioritariamente os consumidores do "choro" e do "samba tradicional". Com efeito, diplomas superiores conquistados em instituições de renome, empregos passíveis de assegurar deferência social, residência em bairros nobres e centrais das duas capitais e a decorrente afeição pelo "bom gosto" em detrimento do "gosto da maioria" distinguem o grupo de amantes do tradicionalmente "belo" na música popular. Se, como visto, o "pagode comercial” divide espaço físico com outros gêneros/subgêneros de fraca respeitabilidade cultural como o rap e o funk, o "choro" e o "samba tradicional" partilham, muito pelo contrário, espaços físicos com os muito mais discriminantes espetáculos teatrais, podendo até mesmo ocupar "teatros", ou seja, locais destinados à encenação de manifestações artísticas consideradas mais legítimas pelas categorias coletivas de percepção e hierarquização das realidades culturais.

Assim, se os gêneros musicais bem estabelecidos na hierarquia dos valores culturais estão diametralmente relacionados com públicos bem assentados no âmbito da hierarquia social, o contrário também é verdadeiro. Nesse contexto, e tendo em vista o recrutamento social dos produtores e dos consumidores das expressões artísticas em questão, o caso do "samba de raiz", representado pelos públicos presentes no Você Vai se Quiser e no Lapa 40, expressa uma inflexão reveladora de como esse subgênero está sendo redefinido do ponto de vista da legitimidade cultural: uma proporção de

11. Sem contar que, entre os estudantes de origem social modesta, não é rara a situação em que as solicitações culturais da família e as da escola são contraditórias. Ver Bourdieu (1993) e Lahire (2006). 
ouvintes socialmente privilegiados divide espaço com outra parcela que apresenta as propriedades sociais do público do "pagode comercial”. O mesmo é válido para seus produtores que, se de um lado buscam aproximar-se dos figurões da MPB e do "samba tradicional", de outro, não abrem mão do sucesso de vendas viabilizado pela coabitação dos espaços propagadores do "pagode comercial" (Trotta, 2006; Fernandes, 2010).

Sem querer exagerar e/ou dramatizar as diferenças intergrupos, o cruzamento de variáveis que lidam diretamente com os atributos relativos aos hábitos de consumo musical produz resultados que são coerentes com as asserções mencionadas. Assim, quando se interroga sobre o apreço pelo choro nas casas de samba e pelo samba nas casas de choro, e, ainda, quando se questiona o eventual gosto pela música clássica (cognome popularizado de "música erudita"), vê-se que também nesse domínio "o capital vai ao capital" ou que, inversamente, as desvantagens em matéria de competência cultural também se exprimem de forma cumulativa.

TABELA 6

Local de Coleta versus Gosto por Choro ou Samba

\begin{tabular}{|c|c|c|c|c|c|c|}
\hline \multirow{2}{*}{$\begin{array}{l}\text { LOCAL DE COLETA } \\
\text { DOS DADOS }\end{array}$} & \multicolumn{2}{|c|}{ GOSTA DE SAMBA? } & \multirow{2}{*}{$\begin{array}{l}\text { LOCAL DE COLETA } \\
\text { DOS DADOS }\end{array}$} & \multicolumn{3}{|c|}{ GOSTA DE CHORO? } \\
\hline & SIM & $\begin{array}{c}\text { SIM } \\
(\text { COM EXEMPLOS })\end{array}$ & & SIM & $\begin{array}{c}\text { SIM } \\
\text { (COM EXEMPLOS) }\end{array}$ & NÃO \\
\hline $\begin{array}{l}\text { Teatro Denoy de Oliveira } \\
\text { (choro, SP) }\end{array}$ & $40,0 \%$ & $60,0 \%$ & $\begin{array}{l}\text { Teatro Fecap } \\
\text { (samba tradicional, SP) }\end{array}$ & $60,0 \%$ & $40,0 \%$ & - \\
\hline $\begin{array}{l}\text { Comuna do Semente } \\
\text { (choro, } \mathrm{RJ} \text { ) }\end{array}$ & $10,0 \%$ & $90,0 \%$ & $\begin{array}{l}\text { Carioca da Gema } \\
\text { (samba tradicional, RJ) }\end{array}$ & $50,0 \%$ & $25,0 \%$ & $25,0 \%$ \\
\hline \multirow[t]{5}{*}{ TOTAL } & $25,0 \%$ & $75,0 \%$ & $\begin{array}{l}\text { Você Vai se Quiser } \\
\text { (samba de raiz, sP) }\end{array}$ & $60,0 \%$ & $25,0 \%$ & $15,0 \%$ \\
\hline & & & $\begin{array}{l}\text { Lapa } 40^{\circ} \\
\text { (samba de raiz, RJ) }\end{array}$ & $35,0 \%$ & $20,0 \%$ & $45,0 \%$ \\
\hline & & & $\begin{array}{l}\text { Porto Alcobaça } \\
\text { (pagode comercial, sP) }\end{array}$ & $35,0 \%$ & - & $65,0 \%$ \\
\hline & & & $\begin{array}{l}\text { Fundição Progresso } \\
\text { (pagode comercial, RJ) }\end{array}$ & $15,0 \%$ & $15,0 \%$ & $70,0 \%$ \\
\hline & & & TOTAL & $42,50 \%$ & $20,80 \%$ & $36,70 \%$ \\
\hline
\end{tabular}

Nessa linha de juízo, o maior ou menor apreço declarado pelo choro, situado no nível mais elevado de excelência musical popular brasileira, serve de parâmetro à verificação da distância diferencial dos distintos públicos desse excelso gênero da música popular. Indo ao encontro do suposto de que uma dimensão do estilo de vida tende a sinalizar todas as outras (Bourdieu, 1979), os dados coletados indicam que o público do "samba tradicional" é o que mais demonstra intimidade com o choro, já que, no teatro Fecap, além de todos os entrevistados se declararem aficionados pelo 
antigo gênero, 40\% deles souberam citar com precisão o nome de artistas de suas predileções ligados ao seleto universo dos chorões, enquanto no Carioca da Gema $50 \%$ declararam apreciá-lo, sendo que $25 \%$ citaram um de seus artistas prediletos, somando $75 \%$ de admiradores. Já a cifra dos amantes do choro no Você Vai se Quiser, onde se difunde o "samba de raiz", chega a $85 \%$, sendo, portanto, bem distinta da anotada em seu homólogo Lapa $40^{\circ}$, onde $55 \%$ se diriam amantes e $45 \%$ declarariam não gostar do gênero, indicação de que um público dotado de gostos de fraca legitimidade cultural possivelmente frequentaria o local ${ }^{12}$.

Como se a separação das salas de espetáculo levasse à distinção progressiva dos públicos, entre os presentes na Porto Alcobaça e na Fundição Progresso, templos do "pagode comercial", a franca maioria declarou não apreciar o choro (65\% e 70\%, respectivamente). Entre os poucos que admiravam o gênero (35\%), nenhum demonstrou possuir conhecimento mínimo a ponto de citar o nome de um chorão na Porto Alcobaça, enquanto parcela ínfima se encontrava apta na Fundição Progresso (15\%). Com o público do Denoy de Oliveira e da Comuna do Semente, onde se difunde o choro, o resultado se inverteu: todos declararam apreciar o samba, e a maioria esmagadora soube citar o nome de ao menos um sambista (60\% e $90 \%$, respectivamente). Ademais, boa parte dos que não citaram sequer um nome o fez com a escusa de que eram tantos os admirados que não teriam como citar somente alguns deles, manifestando, portanto, forte crença na hierarquia dos valores culturais legítimos.

A distância diferencial dos variados públicos em relação ao mundo musical tido como o mais legítimo é ainda mais nitidamente aferida pelo apreço declarado pela "música clássica", gênero que, como visto no início do texto, ocupa as mais altas posições na escala de valores musicais traçada por um dos críticos de música mais importantes de São Paulo.

Nesse sentido chama a atenção, antes de tudo, o fato de que em São Paulo a maioria dos que responderam "sim" à questão sobre a predileção pela música clássica e que, ainda por cima, trataram de citar nomes de compositores famosos estivesse presente no Você Vai se Quiser (50\%), corroborando a asserção anterior sobre a composição social mista e ambivalente dos frequentadores do local. Da mesma forma, o suposto de que a divisão social do público nessa casa que difunde o "samba de raiz" é a que aparenta possuir maior nitidez ganha sentido por meio do alto número dos que declararam não gostar desse gênero musical (40\%).

12. A diferença entre as casas paulistana e carioca explicar-se-ia em razão de o Você Vai se Quiser abrigar também apreciadores do "samba tradicional", mais do que o Lapa $40^{\circ}$, que, pela própria estrutura e diversificação de artistas, atrairia um público bastante heterogêneo mesmo no espetáculo de Arlindo Cruz, ás do "samba de raiz". 
TABELA 7

Local de Coleta versus Gosto por "Música Clássica"

\begin{tabular}{l|c|c|c}
\hline LOCAL DE COLETA DE DADOS & SIM & NÃO & $\begin{array}{c}\text { SIM (COM } \\
\text { EXEMPLOS) }\end{array}$ \\
\hline Teatro Denoy de Oliveira (choro, sP) & $40,0 \%$ & $20,0 \%$ & $40,0 \%$ \\
\hline Comuna do Semente (choro, RJ) & $10,0 \%$ & $10,0 \%$ & $80,0 \%$ \\
\hline Teatro Fecap (samba tradicional, sP) & $45,0 \%$ & $35,0 \%$ & $20,0 \%$ \\
\hline Carioca da Gema (samba tradicional, RJ) & $20,0 \%$ & $35,0 \%$ & $45,0 \%$ \\
\hline Você Vai se Quiser (samba de raiz, SP) & $10,0 \%$ & $40,0 \%$ & $50,0 \%$ \\
\hline Lapa 40 (samba de raiz, RJ) & $10,0 \%$ & $70,0 \%$ & $20,0 \%$ \\
\hline Porto Alcobaça (pagode comercial, sP) & - & $95,0 \%$ & $5,0 \%$ \\
\hline Fundição Progresso (pagode comercial, RJ) & $30,0 \%$ & $65,0 \%$ & $5,0 \%$ \\
\hline TOTAL & $20,0 \%$ & $46,0 \%$ & $34,0 \%$ \\
\hline
\end{tabular}

Ainda que a divisão entre os públicos do "samba tradicional" e do "choro" tenha se manifestado consideravelmente neste quesito, é coerente com o que foi visto até aqui o fato de que a menor parcela dos que afirmaram não apreciar a "música clássica" integrava os frequentadores de espetáculos de "choro" (20\% no Denoy de Oliveira e $10 \%$ na Comuna do Semente), exprimindo assim a proximidade que este pequeno público de amantes de "música para músicos" no âmbito popular guarda com a forma legítima erudita. A maioria esmagadora que se declarou aficionada de “música clássica”, citando ou não nomes de compositores, também estava representada pelo público do teatro Denoy de Oliveira (80\%) e da Comuna do Semente (90\%), seguida do teatro Fecap (65\%) e do Carioca da Gema (65\%), do Você Vai se Quiser (60\%) e, por fim e distante dos demais, do Lapa 40 (30\%), da Fundição Progresso (35\%) e da Porto Alcobaça (5\%). Mesmo esperada, impressiona a quantidade de entrevistados no meio do "pagode comercial" em São Paulo que rechaça a "música clássica" (95\%), assim como no Lapa 40 (70\%) e na Fundição Progresso (65\%). A distância desses públicos em relação às formas artísticas mais legítimas exprime-se também na ausência de uma atitude de "blefe cultural" (Lahire, 2006), que leva a subestimar as práticas menos nobres, e mesmo de "boa vontade cultural" (Hoggart, 
1973), isto é, de certa docilidade e reverência ante a cultura erudita por parte daqueles que são muitas vezes dela desapossados ${ }^{13}$.

Mesmo que se saiba que não é necessariamente o maior número de praticantes que faz com que uma norma cultural seja legítima (Pinto, 2004), não deixa de surpreender que uma taxa tão elevada dos que declararam não gostar de "música clássica” surgisse entre os ouvintes do "samba tradicional" no teatro Fecap e no Carioca da Gema (35\% em ambos). Sobre tal resultado relativamente alto, pode-se lançar a hipótese de que o nacionalismo próprio às expressões artísticas populares venha possivelmente a desencorajar a audição da música que não seja puramente "nossa", do "povo"14.

Por fim, está ainda em consonância com as considerações empreendidas até aqui a análise de dados advindos de fonte diversa e temporalmente deslocada, no caso, os relativos à audiência de rádio das pesquisas do instituto Ibope entre os anos de 1994 e 1999. O escrutínio de material que traz informações sobre o arranjo institucional referente a um veículo de comunicação no período que compreende o apogeu do "pagode comercial” (Trotta, 2006) tem a serventia de auxiliar o escoramento da hipótese de que o mecanismo estrutural que informa as distinções operadas entre os gêneros e subgêneros musicais em pauta pôs-se em funcionamento a partir do instante em que o "pagode comercial" arregimentou um grande público. Ressalte-se, no entanto, que por se tratar de uma pesquisa de mercado, não embasada em critérios e finalidades sociológicas, há escassez de detalhes valiosos para que as conclusões ensaiadas possuíssem menor inexatidão, sobretudo pela impossibilidade de se desagregarem as variáveis apresentadas. Por outro lado, o enorme número de questionários aplicados em pesquisas desse porte auxilia a visualização, grosso modo, de tendências difíceis de verificar a partir dos dados trabalhados aqui ${ }^{15}$.

As Tabelas 8 e 9 trazem os atributos dos ouvintes de oito estações de rádio de São Paulo e do Rio de Janeiro em frequência modulada. A seleção dessas estações orientou-se pela difusão predominante dos gêneros e subgêneros musicais em pauta nos seus programas diários ${ }^{16}$. Em São Paulo, a Transcontinental e a 105 FM, que neste

13. A negação ostensiva de práticas positivamente classificadas (e classificantes) denunciaria, na visão de Bourdieu, uma ambição de inserção frustrada e, desse modo, a impotência de se identificar às disposições legítimas (Bourdieu, 1979, p. 91).

14. Sobre as razões históricas que conferem plausibilidade a esse posicionamento, ver Fernandes (2010). A respeito da legitimação nacionalista do samba e de sua transformação em música "autenticamente nacional” e definidora do próprio pertencimento à sociedade brasileira, ver, ainda, Rivron (2010), Stroud (2008) e McCann (2004).

15. Essas pesquisas costumam fazer uso da aplicação de duzentos questionários por dia durante o período trimestral avaliado, conforme informam as folhas de resultado do Ibope.

16. Guiamo-nos pelo relato de diversos agentes entrevistados no âmbito da pesquisa e por demais verificações realizadas em revistas e publicações especializadas, como Cavaco, Pagodenopé, Revista da Música Popular, Roda de Choro, entre outras. 
TABELA 8

Rádios Selecionadas no Rio de Janeiro versus Diversos Atributos*

\begin{tabular}{|c|c|c|c|c|c|}
\hline \multirow{2}{*}{\multicolumn{2}{|c|}{ MÉDIA TOTAL }} & \multicolumn{4}{|c|}{ RÁDIOS } \\
\hline & & \multirow{2}{*}{$\begin{array}{r}98 \mathrm{FM} \\
16,6955\end{array}$} & \multirow{2}{*}{$\begin{array}{c}\text { TROPICAL } \\
3,6515\end{array}$} & \multirow{2}{*}{$\begin{array}{l}\text { MEC } \\
0,325\end{array}$} & \multirow{2}{*}{$\begin{array}{c}\text { Jв } \\
3,5155\end{array}$} \\
\hline Participação & $\%$ & & & & \\
\hline \multirow{2}{*}{ Sexo } & Homem & 32,05 & 52,25 & 53,8 & 52,6 \\
\hline & Mulher & 67,95 & 47,75 & 46,2 & 47,4 \\
\hline \multirow{3}{*}{ Classe social } & $\mathrm{AB}$ & 22,85 & 18,35 & 64,35 & 58,15 \\
\hline & C & 39,55 & 38,95 & 24,8 & 31,6 \\
\hline & $\mathrm{DE}$ & 37,6 & 42,7 & 10,85 & 10,25 \\
\hline \multirow{6}{*}{ Idade } & 10 a 14 & 8,8 & 4,15 & 1,4 & 0,65 \\
\hline & 15 a 19 & 11,9 & 7,45 & 3,3 & 3,05 \\
\hline & 20 a 24 & 13,35 & 12,15 & 3,9 & 9,25 \\
\hline & 25 a 29 & 14 & 14,7 & 4,9 & 13,65 \\
\hline & 30 a 39 & 25,95 & 26,0 & 14,8 & 34,1 \\
\hline & $40+$ & 26 & 35,55 & 71,7 & 39,3 \\
\hline \multirow{2}{*}{ Atividade } & Ativo & 58 & 70,15 & 61,8 & 82,75 \\
\hline & Inativo & 42 & 29,85 & 38,2 & 17,25 \\
\hline \multirow{3}{*}{ Instrução } & 1 & 42,6 & 44,2 & 12,2 & 6,4 \\
\hline & 2 & 52,4 & 51,45 & 35,35 & 58,2 \\
\hline & 3 & 5 & 4,35 & 52,45 & 35,4 \\
\hline
\end{tabular}

${ }^{*}$ Visto que a periodicidade da pesquisa era trimestral, os resultados apresentados consistem no produto da soma e divisão dos números informados pelas enquetes que abarcaram os trimestres relativos aos anos de 1994 a 1999.

interlúdio se postavam entre as mais ouvidas da cidade - sobretudo a Transcontinental, líder de audiência durante boa parte do tempo recortado -, executavam em suas grades os sucessos do "pagode comercial" daquele momento. Apresentavam de forma minoritária, sobretudo nas madrugadas, programas em que o "samba de raiz" predominava, como ainda praticavam inserções pontuais do subgênero na programação ao longo do dia. No Rio de Janeiro, as estaçóes selecionadas como espelhos das paulistas foram a 98 FM e a Tropical. A 98 FM fazia exatamente as vezes da Transcontinental, sobretudo por ocupar o posto de uma das estações mais ouvidas da capital carioca durante o ínterim selecionado. A Tropical, por outro lado, apesar de também basear sua programação no "pagode comercial", era a que historicamente mais abria espaço aos "sambistas de raiz", haja vista ter sido uma das primeiras estações a sustentar a ascensão de Zeca Pagodinho \& Cia nos anos de 1980. As quatro representarão, destarte, as instituições agregadoras do público referente ao "pagode comercial" e ao "samba de raiz", sendo-nos impossível alcançar uma separação mais acurada. Já a Rádio usp e a Musical em São Paulo, e a Rádio mec e a Rádio Jornal do Brasil, no Rio de Janeiro, posicionar-se-iam do outro lado do espectro: com grades baseadas 
em MPB, "samba tradicional", escassos choros e outras espécies de música popular de "bom gosto”, essas rádios não abriam espaço aos blockbusters musicais do momento, tampouco a "sambas de raiz", representando antes as estações irradiadoras de músicas nacionais de "qualidade".

TABELA 9

Rádios Selecionadas em São Paulo versus Diversos Atributos

\begin{tabular}{|c|c|c|c|c|c|}
\hline \multirow{2}{*}{\multicolumn{2}{|c|}{ MÉDIA TOTAL }} & \multicolumn{4}{|c|}{ RÁdIOS } \\
\hline & & \multirow{2}{*}{$\begin{array}{c}\text { TRANSCONTINENTAL } \\
9,64\end{array}$} & \multirow{2}{*}{$\begin{array}{l}105 \mathrm{FM} \\
4,8045\end{array}$} & \multirow{2}{*}{$\frac{\text { MUSICAL }}{1,541}$} & \multirow{2}{*}{$\begin{array}{c}\text { USP } \\
0,211\end{array}$} \\
\hline Participação & $\%$ & & & & \\
\hline \multirow{2}{*}{ Sexo } & Homem & 43,8 & 46,45 & 7,75 & 62,9 \\
\hline & Mulher & 56,2 & 53,55 & 62,25 & 37,1 \\
\hline \multirow{3}{*}{ Classe social } & $\mathrm{AB}$ & 24,35 & 20,6 & 69,6 & 58,8 \\
\hline & C & 44,25 & 44,15 & 24,05 & 31,6 \\
\hline & $\mathrm{DE}$ & 31,4 & 35,25 & 6,35 & 9,6 \\
\hline \multirow{6}{*}{ Idade } & 10 a 14 & 13,1 & 13,15 & 1,9 & 2,8 \\
\hline & 15 a 19 & 24,3 & 28,95 & 6,05 & 6,1 \\
\hline & 20 a 24 & 20 & 21,2 & 13,6 & 15 \\
\hline & 25 a 29 & 12,65 & 13,05 & 19,2 & 14,75 \\
\hline & 30 a 39 & 17 & 14,4 & 34,7 & 37,25 \\
\hline & $40+$ & 12,95 & 9,25 & 24,55 & 24,1 \\
\hline \multirow{2}{*}{ Atividade } & Ativo & 58 & 70,15 & 61,8 & 82,75 \\
\hline & Inativo & 42 & 29,85 & 38,2 & 17,25 \\
\hline \multirow{3}{*}{ Instrução } & 1 & 47,1 & 21 & 8,65 & 15,05 \\
\hline & 2 & 50,05 & 47,25 & 50 & 50,05 \\
\hline & 3 & 2,85 & 1,75 & 41,35 & 25,9 \\
\hline
\end{tabular}

Tomando como base de análise a audiência das rádios que reproduziam o "pagode comercial" e o "samba de raiz" em ambas as cidades, observa-se que a maioria dos seguidores era formada pelo público feminino, com a exceção da Tropical, onde uma pequena diferença pró-sexo masculino foi notada (52,25\% de homens contra $47,75 \%$ de mulheres). O oposto sucedia com as rádios de "qualidade", ou seja, os homens eram os que mais as sintonizavam no geral, a não ser no caso da Musical FM, que apresentava leve maioria feminina (os mesmos $52,25 \%$ versus $47,75 \%$ vistos na Tropical se repetiam de forma invertida). Tal constatação corrobora a opinião expressa por um empresário do "pagode comercial", Jorge Hamilton, quando questionado sobre o motivo de não lidar com grupos de samba femininos:

Não teria mercado para as mulheres no pagode. $90 \%$ de quem vai a um show de pagode é mulher. Rolaria um ciúme no clima de ver outras mulheres no palco. Elas querem ver o garoto 
bonitinho, dançando, fazendo uma graça, rebolando. Restringe muito por causa do público feminino, que é muito grande. É quase que maioria absoluta $[. . .]^{17}$.

A inexistência de mulheres no desempenho de funções artísticas no "pagode comercial" mostra a interdição que compunha a injunção central naquela figuração: aos homens caberia única e exclusivamente o papel ativo na relação estabelecida entre os sexos, o de artistas sensuais e alvos de cobiça das mulheres espectadoras. $\mathrm{O}$ resultante impulso mimético animaria os participantes masculinos do jogo a procurarem a inserção nessa esfera artística abarrotada de jovens mulheres dispostas ao fanatismo, à entrega total e repleta de oportunidades de meteórica ascensão socioeconômica.

Os números do Ibope, por sua vez, confirmam o fato de que o funcionamento desse mercado girava em torno de um público com menos de 25 anos de idade, proveniente de baixas camadas sociais $(77,15 \%$ e $81,65 \%$ dos ouvintes das rádios 98 FM e Tropical provinham das classes C, D e E, respectivamente, o mesmo ocorrendo com 75,65\% e 79,40\% dos ouvintes da Transcontinental e da 105 FM). Tais rádios propagadoras das manifestações musicais de mais fraca legitimidade cultural recrutariam ainda e predominantemente um público pouco escolarizado (apenas $5 \%$ e $4,35 \%$ possuíam o terceiro grau entre os ouvintes da 98 FM e Tropical, e 2,85\% e 1,75\% entre os da Transcontinental e 105 FM). O precário posicionamento social desse público torna inteligíveis não apenas as manifestações de adoração exagerada cristalizadas nos fã-clubes e na histeria ${ }^{18}$, como a inserção artística pouco convincente de seus produtores (ostentação e sujeição aos poderes temporais etc.), invariavelmente contestados pelos detentores da autoridade musical legítima.

A única discrepância relevante que pôde ser observada entre os ouvintes do "pagode comercial" e do "samba de raiz" das cidades de São Paulo e do Rio de Janeiro em todos os quesitos verificados ocorreu em relação à faixa etária. Ao passo que a Transcontinental e a 105 FM, difusoras dos grandes sucessos do "pagode comercial", registravam respectivamente percentuais de 57,4\% e 63,30\% de ouvintes abaixo dos 25 anos, as cariocas Tropical e 98 FM, mais voltadas ao "samba de raiz", atraíam um perfil mais adulto, em que somente $23,75 \%$ e $34,05 \%$, respectivamente, apresentavam menos do que 25 anos $^{19}$.

Com respeito às quatro estações de maior autoridade cultural, o retrato simplesmente se inverte. Além de possuírem público-alvo constituído de forma levemente majoritária por homens - supostamente ouvintes mais "sérios" e comprometidos

17. Declaração feita por Jorge Hamilton em 2006 a um dos autores deste texto.

18. Sobre a relação entre uma forma de arte menos pura e um público menos contido, ver Charle (2012).

19. Ainda assim, o público permanece sendo mais jovem do que aquele das rádios culturalmente mais legítimas. 
com a audição "musical", e não com o derramamento de paixões associado ao sexo feminino -, os receptores dessas rádios detinham títulos universitários (41,35\% e $25,9 \%$ na Musical e na Usp, e 52,45\% e 35,4\% na MEC e na Jornal do Brasil), posicionavam-se majoritariamente nas "classes $\mathrm{AB}$ " $(69,6 \%$ e $58,8 \%$ entre os ouvintes da Musical e da Usp e 64,35\% e 58,15\% em meio aos da MEC e da Jornal do Brasil) e, além do mais, concentravam-se em bloco nas idades mais avançadas (59,25\%, $61,35 \%, 86,5 \%$ e $73,4 \%$ de ouvintes com mais de 30 anos de idade das estações Musical, UsP, MEC e Jornal do Brasil, respectivamente).

Como se a separação de gêneros levasse à progressiva separação das salas de espetáculos e das rádios e, inelutavelmente, dos públicos, vê-se, uma vez mais, que as expressões artísticas mais valorizadas na hierarquia que estrutura o campo musical recrutam predominantemente ouvintes igualmente bem qualificados em termos sociais. Se, a despeito das mudanças ocorridas no interior desse microcosmo - que, como visto, viu emergir um subgênero do samba de forte apelo comercial -, continua a existir um vínculo não negligenciável entre bens culturais e grupos sociais, então é porque a classificação das coisas muitas vezes ainda segue de perto a classificação dos homens (Durkheim e Mauss, 1981).

\section{Considerações finais}

Tendo-se guiado pelo objetivo mais amplo de estabelecer as condições em que são produzidos os consumidores de bens musicais, as diferentes maneiras de apropriação dessas expressões artísticas e as condições sociais de constituição do modo de apropriação que é tido por legítimo, este texto discutiu algumas evoluções contemporâneas no âmbito da produção e da difusão do samba e do choro na capital paulista e no Rio de Janeiro. Inscrevendo-se num debate candente no domínio da sociologia do gosto - o que opõe, de um lado, a tese da homologia estrutural entre o espaço de produção dos bens simbólicos e o espaço dos consumidores desses bens e, de outro lado, a que atenua o peso do pertencimento social na conformação do juízo de gosto $^{20}$-, a pesquisa cujos resultados preliminares apresentamos aqui orienta a concluir que a posição social permanece um determinante maior dos gostos em matéria de música. Com efeito, a probabilidade desigual de acesso aos diferentes bens musicais faz com que no início do século XXI ainda se observe uma não negligenciável correspondência entre a hierarquia das artes (e dos gêneros) e a hierarquia social dos consumidores. Diferentemente dos que postulam uma desierarquização progressiva dos acervos estéticos e põem em causa a correspondência

20. Para uma reconstituição do debate polarizado por essas duas tendências, ver Pulici (2010). 
entre posições sociais e disposições estéticas (Fabiani, 2003, 2005), a investigação exploratória aqui discutida autoriza a afirmar que, ao menos no Brasil e a respeito de dois de seus gêneros musicais populares urbanos mais tradicionais, o consumo cultural continua a cumprir uma função de legitimação das diferenças sociais. Se, como notou Julien Duval sobre o gosto cinematográfico, o "sucesso comercial" e o "sucesso de estima" constituem as duas grandes formas de excelência no universo do cinema (Duval, 2011), pode-se dizer que, no caso do choro e do samba (e seus subgêneros) aqui em foco, as expressões musicais que alcançam a primeira dessas duas formas de reconhecimento são menos dignificadas pelas instâncias de consagração cultural que são específicas ao campo da música e, a um só tempo, mais acolhidas pelo público que é, ele também, o menos favorecido no âmbito das relações de força que atravessam a sociedade.

Ainda assim, e como explicitado nos esclarecimentos metodológicos do início do texto, este primeiro levantamento só poderá dar todos os seus frutos quando conseguirmos não apenas realizar um survey específico a partir de uma amostra representativa do público presente nos espetáculos selecionados, mas abordar também a apropriação diferencial das mesmas obras musicais e as diferentes categorias de percepção e fruição de produtos culturais relativamente semelhantes, pois, como se sabe, mesmo os bens simbólicos mais industrializados não possuem características objetivas uniformemente percebidas e apreciadas, e, em suma, capazes de se imporem como tais a todo e qualquer indivíduo.

\section{Referências Bibliográficas}

Alves, Carolina G. (2009), O choro que se aprende no colégio: a formação de chorões na Escola Portátil de Música do Rio de Janeiro. Rio de Janeiro, dissertação de mestrado, Departamento de Sociologia, Universidade do Estado do Rio de Janeiro.

Arantes, Silvana. (2005), "Questão de classe". Entrevista com Carlos Lyra. Folha de S.Paulo, 2/9, p. E1.

BArros, Frederico. (2010), "Que importa se é falsa a baiana? O samba dos anos 2000 visto através dos modos de cantar”. Anais do $34^{\circ}$ Encontro Anual da Associação Nacional de Pós-graduação em Ciências Sociais, Caxambu. Disponível em http://www.anpocs.org.br/portal/ index.php?option $=$ com_wrapper\&Itemid=90, consultado em 22/11/2015.

Bellavance, Guy; Ratté, Michel \& Valex, Myrtille. (2004), "Le goût des autres: une analyse des répertoires culturels de nouvelles élites omnivores”. Sociologie et Sociétés, Xxxvi: 27-57.

Botelho, Isaura \& Fiori, Maurício. (2005), "O uso do tempo livre e as práticas culturais na região metropolitana de São Paulo”. Relatório de pesquisa disponibilizado pelo Centro de Estudos da Metrópole - Cebrap. 
Bourdieu, Pierre. (1979), La distinction: critique sociale du jugement. São Paulo, Minuit, 1979. . ([1979] 2008), A distinção: crítica social do julgamento. São Paulo/Porto Alegre, Edusp/Zouk.

. ([1992] 1996), As regras da arte: gênese e estrutura do campo literário. São Paulo, Companhia das Letras.

. (1993), "Les contradictions de l'héritage". In: La misère du monde. Paris, Seuil, 1993.

\& DARBEL, Alain. ([1969] 2003), O amor pela arte: os museus de arte na Europa e seu público. São Paulo/Porto Alegre, Edusp/Zouk.

Bryson, Bethany. (1997), "What about the univores? Musical deslikes and group-based identity construction among Americans with low levels of education”. Poetics, 25: 141-156.

Bustamante, Mauricio \& Garcia, Domingo. (2014), "Distinction's framework: a tool to understand the space of cultural practices in Mexico". In: Coulangeon, Philippe \& Duval, Julien (orgs.). The Routledge companion to Bourdieu's "distinction". Londres, Routledge.

Cazes, Henrique. (1998), Choro: do Quintal ao Municipal. São Paulo, Editora 34.

Charle, Christophe. ([2008] 2012), A gênese da sociedade do espetáculo: teatro em Paris, Berlim, Londres e Viena. São Paulo, Companhia das Letras.

Coulangeon, Philippe. (2004), "Classes sociales, pratiques culturelles et style de vie: le modèle de la distinction est-il (vraiment) obsolète?". Sociologie et Sociétés, 1 (36): 59-85.

Donnat, Oliver. (1999), "La stratification sociale des pratiques culturelles et son évolution 1973-1997”. Revue Française de Sociologie, 1 (xL): 111-119.

Durkheim, Émile \& Mauss, Marcel. (1981), "Algumas formas primitivas de classificação”. In: Rodrigues, José Albertino (org.). Durkheim: Sociologia. São Paulo, Ática.

Duval, Julien. (2011), "L'offre et les goûts cinématographiques en France”. Sociologie, 1 (2): 1-18.

Elias, Norbert \& SCOTson, John. ([1965] 2000), Os estabelecidos e os outsiders: sociologia das relações de poder a partir de uma pequena comunidade. Rio de Janeiro, Zahar.

Fabiani, Jean-Louis. (2003), “Peut-on encore parler de légitimité culturelle?”. In: Donnat, Oliver \& Tolila, Paul. Le(s) public(s) de la culture. Paris, Presses de Sciences Po, pp. 305-317.

Fabiani, Jean-Louis. (2005), Beautés du Sud: la Provence à l'épreuve des jugements de goût. Paris, L'Harmattan.

Featherstone, Mike. (1995), Cultura de consumo e pós-modernismo. São Paulo, Studio Nobel. Fernandes, Dmitri Cerboncini. (2010), A inteligência da música popular: a 'autenticidade' no samba e no choro. São Paulo, tese de doutorado, Faculdade de Filosofia, Letras e Ciências Humanas da Universidade de São Paulo.

FeRnANDES, Florestan. "Análise e crítica do projeto de lei sobre diretrizes e bases da educação nacional". In: BARros, Roque Spencer Maciel de. Diretrizes e bases da educação nacional. São Paulo, Pioneira, 1960, pp. 217-306. 
Fridman, Viviana \& Ollivier, Michèle. (2004), "Goûts, pratiques culturelles et inégalités sociales: branchés et exclus". Sociologie et Sociétés, 1 (xxxvi): 3-11.

Frydberg, Marina Bay. (2011), "Eu canto samba" ou "Tudo isto é fado": uma etnografia multissituada da recriação do choro, do samba e do fado por jovens músicos. Porto Alegre, tese de doutorado em antropologia social, Universidade Federal do Rio Grande do Sul.

HogGaRT, Richard. ([1957] 1973), As utilizaçôes da cultura: aspectos da vida cultural da classe trabalhadora. Lisboa, Editorial Presença, vol. 2.

Lahire, Bernard. ([2004] 2006), A cultura dos indivíduos. Porto Alegre, Artmed.

Livingston-Isenhour, T. E. \& Garcia, T. G. C. (2005), Choro: a social history of a Brazilian Popular Music. Indiana, Indiana University Press.

LizÉ, Wenceslas \& Roueff, Olivier. (2010/1), "La fabrique des goûts”. Actes de la Recherche en Sciences Sociales, 181-182: 4-11.

Marques, Eduardo; Scalon, Celi \& Oliveira, Maria Aparecida. (2008), "Comparando estruturas sociais no Rio de Janeiro e em São Paulo". Dados, 51: 215-238.

McCann, Brian. (2004), Hello, hello Brazil: popular music in the making of modern Brazil. Durham, Duke University Press.

Napolitano, Marcos. (2007), A sincope das ideias: a questão da tradição na música popular brasileira. São Paulo, Perseu Abramo.

\& Wasserman, Maria Clara. (2002), "Desde que o samba é samba: a questão das origens no debate historiográfico sobre a música popular brasileira”. Revista Brasileira de História, 39 (20).

Nestrovski, Arthur. (2006), "Campos recebeu dois gigantes da música”. Folha de S.Paulo, $18 / 7$, p. E2.

Pereira, Carlos Alberto Messeder. (2003), Cacique de Ramos: uma história que deu samba. Rio de Janeiro, E-Papers.

Peterson, Richard A. \& Simkus, Albert. "How musical tastes mark occupational status groups”. In: Lamont, Michèle \& Fournier, Marcel. Cultivating differences: symbolic boundaries and the making of inequality. Chicago, The University of Chicago Press, 1992, pp. 152-186.

Pinto, Louis. (2004), “Comment négocier un tournant?”, EspacesTemps.net, http://espacestemps.net/document778.html, consultado em 12/2006.

Pulici, Carolina Martins. (2010), O charme (in) discreto do gosto burguês paulista: estudo sociológico da distinção social em São Paulo. São Paulo, tese de doutorado, Faculdade de Filosofia, Letras e Ciências Humanas da Universidade de São Paulo.

Puterman, Paulo. (1985), Choro: a construção de um estilo musical. São Paulo, dissertação de mestrado, Faculdade de Filosofia, Letras e Ciências Humanas da Universidade de São Paulo.

Rivron, Vassili. (2010-2011), "Le goût de ces choses bien à nous". Actes de la Recherche en Sciences Sociales, 181-182: 126-141. 
SANDroni, Carlos. (2001), Feitiço decente: transformaçôes do samba no Rio de Janeiro (19171933). Rio de Janeiro, Jorge Zahar/Editora UfRJ.

Stroud, Sean. (2008), The defence of tradition in Brazilian popular music. Londres, Ashgate.

Trotta, Felipe da Costa. (2006), Samba e mercado de música nos anos 1990. Rio de Janeiro, tese de doutorado, Escola de Comunicação, Universidade Federal do Rio de Janeiro.

Warde, Alan \& Bennett, Tony. (2008), "A culture in common: the cultural consumption of the UK managerial elite". In: Savage, Mike \& Williams, Karel. Remembering elites. Oxford, Blackwell, pp. 240-259.

Wasserman, Maria Clara. (2002), “Abre a cortina do passado”: A Revista da Música Popular e o pensamento folclorista (Rio de Janeiro: 1954-1956). Curitiba, dissertação de mestrado em história social, Universidade Federal do Paraná.

Weber, Max. ([1922] 2000), "A distribuição do poder da comunidade: classes, estamentos, partidos". In: Economia e sociedade: fundamentos de sociologia compreensiva. Brasília, Editora da UnB, vol. 2, pp. 175-186.

\section{Resumo}

Gosto musical e pertencimento social: O caso do samba e do choro no Rio de Janeiro e em São Paulo Com base em dados levantados em questionários aplicados entre 2006 e 2009 ao público de oito casas de espetáculo de São Paulo e do Rio de Janeiro dedicadas à difusão do choro e do samba (e seus subgêneros), este artigo argumenta que a hierarquia culturalmente reconhecida desses gêneros e subgêneros corresponde à hierarquia social de seus consumidores. Apesar da atual popularidade acadêmica do postulado do ecletismo cultural e dos consumidores "omnívoros", a desigual probabilidade de acesso a esses diferentes bens musicais faz com que ainda se possa afirmar que o espaço de produção e propagação do samba e do choro nessas duas capitais brasileiras mantém uma relação de homologia com o espaço social em que são recrutados os ouvintes desse tipo de música.

Palavras-chave: Gosto musical; Pertencimento social; Choro; Samba; Música popular brasileira. 


\section{Abstract}

Musical taste and social belonging: the case of samba and choro in Rio de Janeiro and São Paulo Based on data collected through questionnaires applied between 2006 and 2009 to the audience of eight concert houses dedicated to Choro and Samba (and its subgenres) in São Paulo and Rio de Janeiro, this paper argues that the culturally recognized hierarchy of these genres and subgenres corresponds to the social hierarchy of their consumers. Despite the prevailing assumption of cultural eclecticism and "cultural omnivores", unequal probability of access to these different musical goods means we can still postulate that the space of production and propagation of Samba and Choro in these two Brazilian capitals maintains a relationship of homology with the social space in which are recruited the listeners of this type of music.

Keywords: Musical taste; Social belongingness; Choro; Samba; Brazilian popular music.

Texto recebido em 17/1/2016 e aprovado em 2/2/2016. DoI: 10.11606/0103-2070.ts.2016. 109800.

Dmitri Cerboncini Fernandes é bacharel em ciências sociais, doutor em sociologia e pós-doutor em história social pela Universidade de São Paulo, com estágio sanduíche na École des Hautes Études en Sciences Sociales - Paris. É professor adjunto do Departamento de Ciências Sociais do ICH-UFJF e autor de Sentinelas da tradição (Edusp, no prelo), além de diversos artigos sobre música e ciências sociais. E-mail: vivaraiz@gmail.com.

Carolina Pulici é professora de sociologia do Departamento de Ciências Sociais da Unifesp e autora de Entre sociólogos (Edusp/Fapesp), além de diversos artigos sobre as lógicas sociais do gosto e o estilo de vida das elites de São Paulo. E-mail: carolinapulici@gmail.com. 


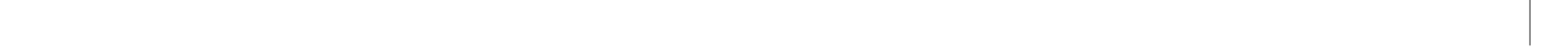

